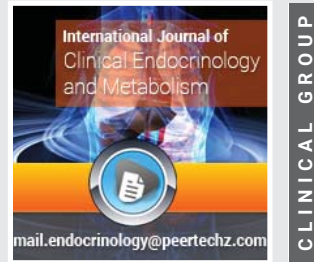

\section{Hypoglycemia as first presentation of insulin \\ resistance-A case report}

\author{
Sourya Sourabh Mohakuda ${ }^{1}$ and J Muthukrishnan ${ }^{2 *}$ \\ ${ }^{1}$ Clinical Tutor, General Medicine, AFMC, Pune, India \\ 2Professor in Medicine and Endocrinology, Department of Endocrinology, Base Hospital, Delhi \\ Cantonment, New Delhi, Delhi 110010, India
}

Received: 26 December, 2019

Accepted: 27 January, 2020

Published: 28 January, 2020

*Corresponding author: J Muthukrishnan, Professor in Medicine and Endocrinology, Department of Endocrinology, Base Hospital, Delhi Cantonment, New Delhi, Delhi 110010, India, Tel: +91-9145630535/ +918698951237; E-mail: jmuthukrishnan@hotmail.com

Keywords: Post prandial hypoglycemia; Insulin resistance; Glycemic index; Alpha glucosidase inhibitors

https://www.peertechz.com

\section{Check for updates}

\title{
Abstract
}

Post prandial hypoglycemia refers to low blood glucose levels in the post meal period. In absence of any gastro-intestinal abnormality or surgery, other less common conditions need consideration. Extended glucose tolerance test helps confirm the diagnosis. The timing of hypoglycemia post meals and the corresponding insulin and C-peptide values help in understanding its pathophysiology. Hyperinsulinemia in Insulin resistance can also rarely present initially with post meal hypoglycemia. Frequent low glycemic index meals along with alpha-glucosidase inhibitors help alleviating the symptoms. We report this case for its rarity and clinical relevance.

\section{Introduction}

There is no clear cut consensus in defining glucose levels that defines hypoglycaemia. However in practice, plasma glucose level (BG) below $54 \mathrm{mg} / \mathrm{dl}$ in non-diabetic individuals and below 70mg/dl in diabetics is considered as hypoglycaemia [1].

In non-diabetic individuals the hypoglycaemia can be either fasting or post prandial. While insulinoma is suspected in cases with fasting hypoglycaemia, dumping syndromes predominate the causes for post prandial hypoglycaemia $[2,3]$.

We present a case with late onset post prandial hypoglycaemic symptoms and discuss the approach and management of such a problem.

\section{Case presentation}

A 55-year old lady, presented to the out-patient department with complaints of several episodes of dizziness 3-4hours post meals for a period of one year. She had no other significant past illness or surgeries and was not on any drugs. She was obese ( Wt $77.8 \mathrm{~kg}$, BMI $32 \mathrm{~kg} / \mathrm{m}^{2}$, waist circumference $104 \mathrm{~cm}$ ). Her pulse was 76 per min, blood pressure was $126 / 80 \mathrm{mmHg}$. She had markers of insulin resistance in the form of acanthosis nigricans and skin tags. Systemic examination was normal.
Her fasting plasma glucose was $98 \mathrm{mg} / \mathrm{dl}$, HDL $34 \mathrm{mg} / \mathrm{dl}$ and triglycerides level was $168 \mathrm{mg} / \mathrm{dl}$. She used to keep fasts for 24 hours off and on for religious purpose and had no history suggestive of similar episodes in those days.

A possibility of post prandial hypoglycaemia was considered and she was advised to check her blood glucose levels with a glucometer when symptomatic. The relevant findings during these episodes are as given below Table 1.

Based on the above findings, she was subjected to a extended Glucose Tolerance Test (eGTT) in which $75 \mathrm{gm}$ of glucose post 10 hours of fasting was administered orally and the blood samples were drawn every 6omins for next 4 hours. Care was taken to stop the test if symptomatic hypoglycaemia develops.

Table 1: Details of events where patient was symptomatic.

\begin{tabular}{|c|c|c|c|c|}
\hline $\begin{array}{c}\text { Sr No of } \\
\text { episodes }\end{array}$ & $\begin{array}{c}\text { Time elapsed } \\
\text { post meal }\end{array}$ & $\begin{array}{c}\text { Glucometer } \\
\text { reading }\end{array}$ & $\begin{array}{c}\text { Relief by } \\
\text { biscuits/ } \\
\text { chocolates }\end{array}$ & $\begin{array}{c}\text { Time taken to get } \\
\text { relived of symptoms }\end{array}$ \\
\hline 1 & $2 \mathrm{~h} 45 \mathrm{mins}$ & $54 \mathrm{mg} / \mathrm{dl}$ & yes & $10-15 \mathrm{mins}$ \\
\hline 2 & $2 \mathrm{~h} 40 \mathrm{mins}$ & $46 \mathrm{mg} / \mathrm{dl}$ & yes & $10-15 \mathrm{mins}$ \\
\hline 3 & $3 \mathrm{~h} 10 \mathrm{mins}$ & $56 \mathrm{mg} / \mathrm{dl}$ & yes & $10-15 \mathrm{mins}$ \\
\hline 4 & $3 \mathrm{~h} 05 \mathrm{mins}$ & $52 \mathrm{mg} / \mathrm{dl}$ & yes & $10-15 \mathrm{mins}$ \\
\hline
\end{tabular}


Her blood glucose levelswere analysed from the samples Figure 1.

Although the fasting blood sugar was normal and had a physiological rise till post 2hours. However the BSL was 62mg/ $\mathrm{dl}$ at $3 \mathrm{hr}$ and $54 \mathrm{mg} / \mathrm{dl}$ at $4 \mathrm{hr}$ of eGTT.

On the sample collected at $4^{\text {th }}$ hour of eGTT and the fasting sample, serum insulin and c- peptides levels were analysed Table 2.

\section{$B S L$ in $\mathrm{mg} / \mathrm{dl}$}

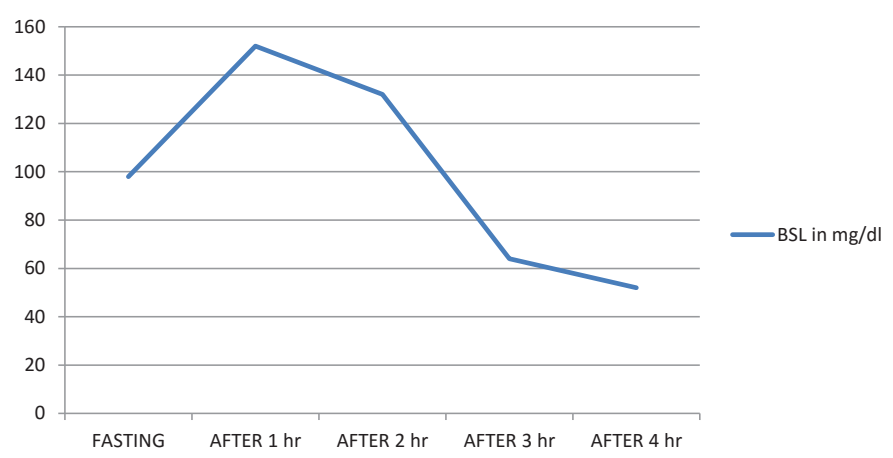

Figure 1: Profile of Egtt.

Table 2: Insulin and c peptide levels at fasting and at $4^{\text {th }}$ hour of eGTT.

\begin{tabular}{|c|c|c|}
\hline & At fasting & 4hr of eGTT \\
\hline $\begin{array}{c}\text { Insulin } \\
(\mu \mathrm{U} / \mathrm{ml})\end{array}$ & 14 & 22 \\
\hline $\begin{array}{c}\text { C-Peptide } \\
(\mathrm{nmol} / \mathrm{l}) \\
(0.5-2.0 \mathrm{nmol} / \mathrm{l})\end{array}$ & 0.72 & 0.92 \\
\hline
\end{tabular}

The levels of insulin and c peptide were disproportionately high in the setting of hypoglycaemia where it was expected to be nearly absent.

Her homeostatic model assessment score for insulin resistance (HOMA-IR) based on fasting glucose and insulin levels were 3.39, suggestive of moderate insulin resistance.

Her renal and liver functions were normal. Radiological imaging of the abdomen did not reveal any abnormality. An upper gastrointestinal endoscopy was done which revealed a normal study. She was explained to be on frequent low caloric meal which contained food with low glycemic index such as green vegetable and fruit. High glycemic index contents such as bakery, refined flour, rice and potatoes were avoided. Regular exercise was emphasised to target a weight loss of $3-4 \mathrm{~kg}$ in 3months. She was also started on Tab Acarbose $25 \mathrm{mg}$ thrice a day with the major meals. She has been of follow up since last 01year, achieved weight loss of $5 \mathrm{kgs}$ and has been asymptomatic. An extended GTT was repeated after 01month which revealed a normal study. In view of hyperinsulinemic hypoglycaemia, with an elevated HOMA-IR, and no other etiology found to explain post-prandial hypoglycaemia, she was diagnosed to have insulin resistance leading to post prandial hypoglycaemia. She has been advised regular follow up for recurrence of symptoms and development of DM.

\section{Discussion}

Post prandial hypoglycaemia which occurs around 2-4hours post meal is suggestive of a late dumping syndrome. The influx of carbohydrate into the intestine causing inappropriately high insulin secretion is one explanation of this phenomenon. The above explanation holds good when there is a prior surgery involving the gastrointestinal tract causing anatomical and physiological deregulation in intestinal motility.

In an individual with no such abnormality, with clinical features and HOMA-IR score suggestive of insulin resistance, it is the likely cause forpost prandial hypoglycaemia. In obese individuals and in patients with metabolic syndrome, such events have been described. There are four Glucose transporters (GLUT) in the body, numbered GLUT1-4 [2]. Amongst these, the GLUT 1-3 is independent of insulin for their functioning while GLUT 4 is insulin dependent. In individuals with metabolic syndrome, underlying insulin resistance is the primary defect. Post meals, the GLUT 1-3 receptors activate and cause the post prandial surge of glucose to normalise. Although the insulin secretion keeps increasing at this stage, the insertion of GLUT4 receptor is delayed in the background of insulin resistance. When the blood glucose level is normalised, the absolute increase in insulin levels cause the small amount of GLUT4 receptors to insert at the target. This small amount of GLUT4 receptors can cause hypoglycaemia when the blood glucose level is normal. This pathophysiology also explains why rarely Type 2 diabetics present as post prandial hypoglycaemia as their first symptom in the initial course of their disease.

Our case had clinical features and biochemical evidence (HOMA-IR) to suggest insulin resistance. The timing of hypoglycaemia post meals, disproportionately raised insulin and C-peptide levels at hypoglycaemia indicate that insulin resistance was the likely cause for her post prandial hypoglycaemia after the secondary causes were ruled out after extensive evaluation. Post prandial hypoglycaemia has been described earlier in non diabetic patients with good insulin sensitivity [3]. In our review of literature, we were not able to find any other case report of hypoglycaemia being the first presentation of insulin resistance.

Acarbose inhibits the action of glycoside hydrolases leading to slowing down of digestion of complex carbohydrates [4]. The low glycemic index food also prevent the sudden surge of plasma glucose levels which inturn neutralise the abrupt rise in the secretion of insulin [5]. Our case has remained asymptomatic with weight loss, low glycemic index food taken at regular frequent intervals and tablet Acarbose 25mg taken thrice a day. On follow up over the past one year, our case has remained asymptomatic, normoglycemic with a normal extended glucose tolerance test.

\section{References}

1. Low Blood Glucose (Hypoglycemia). NIDDK. National Institute of Diabetes and Digestive and Kidney Diseases. Link: http://bit.ly/38LAjv0 
2. Navale AM, Paranjape AN (2016) Glucose transporters: physiological and pathological roles. Biophys Rev 8: 5-9. Link: http://bit.ly/30ZPkGC

3. Brun JF, Fedou C, Mercier J (2000) Postprandial reactive hypoglycemia. Diabetes Metab 26: 337-351. Link: http://bit.ly/3aRXk1g
4. Rosak C, Mertes G (2012) Critical evaluation of the role of acarbose in the treatment of diabetes: patient considerations. Diabetes Metab Syndr Obes Targets Ther 5: 357-367. Link: http://bit.ly/2RWSyGS

5. About Glycemic Index. Glycemic Index Foundation. Link: http://bit.ly/3aNP2Yc
Discover a bigger Impact and Visibility of your article publication with Peertechz Publications

\section{Highlights}

* Signatory publisher of ORCID

* Signatory Publisher of DORA (San Francisco Declaration on Research Assessment)

* Articles archived in worlds' renowned service providers such as Portico, CNKI, AGRIS, TDNet, Base (Bielefeld University Library), CrossRef, Scilit, J-Gate etc.

* Journals indexed in ICMJE, SHERPA/ROMEO, Google Scholar etc.

* OAI-PMH (Open Archives Initiative Protocol for Metadata Harvesting)

- Dedicated Editorial Board for every journal

* Accurate and rapid peer-review process

* Increased citations of published articles through promotions

* Reduced timeline for article publication

Submit your articles and experience a new surge in publication services

(https://www.peertechz.com/submission).

Peertechz journals wishes everlasting success in your every endeavours.

Copyright: @ 2020 Mohakuda SS, et al. This is an open-access article distributed under the terms of the Creative Commons Attribution License, which permits unrestricted use, distribution, and reproduction in any medium, provided the original author and source are credited. 